\title{
Nutritional value and in situ degradability of fruit-vegetable byproducts and their feeding effects on performance of growing Hanwoo steers
}

\author{
Keun Hong Song ${ }^{1}$, Jun Sik Woo ${ }^{1}$, Ju Ri Kim ${ }^{1}$, Gyeong Lim Ryu', Youl Chang Baek², \\ Young Kyoon $\mathrm{Oh}^{2}$, Wan Sup Kwak ${ }^{3}$, and Keun Kyu Park ${ }^{1, *}$
}

\author{
* Corresponding Author: Keun Kyu Park \\ Tel: +82-2-450-3661, Fax: +82-2-455-1044, \\ E-mail: kkpark@konkuk.ac.kr \\ 'Department of Animal Science and Technology, \\ Konkuk University, Seoul 05029, Korea \\ ${ }^{2}$ National Institute of Animal Science, Rural \\ Development Administration, Wanju 55365, Korea \\ ${ }^{3}$ College of Medical Life Sciences, Konkuk University, \\ Chungju 27478, Korea \\ ORCID \\ Keun Hong Song \\ https://orcid.org/0000-0002-3191-3190 \\ Jun Sik Woo \\ https://orcid.org/0000-0003-2201-4502 \\ Ju Ri Kim \\ https://orcid.org/0000-0002-5693-027X \\ Gyeong Lim Ryu \\ https://orcid.org/0000-0002-5903-5705 \\ Youl Chang Baek \\ https://orcid.org/0000-0003-4454-5339 \\ Young Kyoon Oh \\ https://orcid.org/0000-0002-5817-1748 \\ Wan Sup Kwak \\ https://orcid.org/0000-0002-7829-8172 \\ Keun Kyu Park \\ https://orcid.org/0000-0002-8328-3522
}

Submitted Sept 25, 2019; Revised Nov 5, 2019; Accepted Jan 28, 2020
Objective: This study was conducted to evaluate nutritional value and in situ degradability of fruit-vegetable byproducts and their feeding effects on performance of growing Hanwoo steers.

Methods: Nutritional value and in situ degradability of cabbage, Chinese cabbage and fruitvegetable byproducts were assessed. In vivo feeding trial was also performed for 12 weeks. Thirty-six growing steers were randomly allocated into three groups according to body weight (BW) and age in 12 pens ( 4 replications/treatment) and assigned to one of the three dietary treatments: control (byproduct 0\%), FV-B (fruit-vegetable byproduct 20\%), and CA-B (cabbage peel $15 \%$ plus Chinese cabbage peel $15 \%$, total byproduct $30 \%$ ).

Results: The crude protein contents of cabbage, Chinese cabbage and fruit-vegetable byproducts were $18.69 \%, 20.20 \%$, and $10.07 \%$, respectively. Concentrations of neutral detergent fiber (NDF) were higher in cabbage (22.31\%) and Chinese cabbage $(28.83 \%)$ than fruit-vegetable (13.94\%). Higher concentrations of non-fiber carbohydrate were observed for fruit-vegetable (66.72\%) than cabbage (44.93\%) and Chinese cabbage byproducts (24.69\%). The effective degradability (ED) of both dry matter (DM) and NDF for fruitvegetable byproduct (DM, 84.69\%; NDF, 85.62\%) was higher $(\mathrm{p}<0.05)$ than cabbage (DM, 68.47\%; NDF, 55.97\%) and Chinese cabbage byproducts (DM, 68.09\%; NDF, 54.22\%). The DM intake was not different among treatments because the amount of feed was kept constant according to the BW of growing steers to prevent overweight during the growing period. The average daily gain during the whole experimental period was not different among treatments $(1.26,1.25$, and $1.34 \mathrm{~kg} / \mathrm{d}$ for control, FV-B, and CA-B). The ED of both DM and NDF degradability of the total mixed ration (TMR) diets were very similar among treatments. Feed conversion ratio during the whole period showed no significant difference among treatments.

Conclusion: This study demonstrates that fruit-vegetable and cabbage byproducts up to $20 \%$ and 30\% (as fed basis), respectively can be included in TMR diets for growing beef cattle.

Keywords: Beef Cattle; Steer; Performance; Total Mixed Ration (TMR); Fruit Byproduct; Vegetable Byproduct

\section{INTRODUCTION}

Vast amount of wastes is generated worldwide during the production and processing of fruits and vegetables. Porat et al [1] summarized that $45 \%$ and $55 \%$ of all fruits and vegetables are lost and not consumed in the world. In Korea, Chinese cabbage is the most important vegetable to make kimchi, a traditional fermented food. The total annual production of Chinese cabbage and cabbage from 2011 to 2017 in Korea was approximately two and a half million 
tons, and its value is estimated as the fourth largest for cabbage in the world [2]. During the processes of production, postharvest storage, transportation, and further processing, up to $30 \%$ of the total production is discarded as waste [3]. In the wholesale market, which is a stage before distribution to retailers or intermediate merchants, the disposal rate is also very high. For instance, Chinese cabbage occupied 11.1\% $(449,908$ ton/yr) and cabbage $4.5 \%$ (182,175 ton/yr) of the total vegetables traded within the biggest public wholesale market in Seoul, Korea. The amount of wastes generated from fruit and vegetable in this market was $30,076 \mathrm{~kg} / \mathrm{d}$ on average, and waste productions of Chinese cabbage and cabbage estimated 14,831 and $1,483 \mathrm{~kg} / \mathrm{d}$, respectively [4].

The most common method to treat these wastes is throwing them into landfills, which can result in many unpleasant environmental consequences. Although various methods have been proposed to dispose or recycle of fruit and vegetable wastes in wholesale markets and packing houses, their utilization as a feed ingredient for ruminant diets seems to be the most eco-friendly and value-added option [1]. Since these waste resources contain high amounts of moisture, manufacturing high moisture total mixed ration (TMR), blending all feedstuffs into a complete ration that does not require drying process could be the most feasible and economical way.

In addition, fruit and vegetable wastes, having high amount of moisture as well as soluble carbohydrates, can readily be decomposed by putrefying microorganisms, and promote secondary fermentation along with offensive odor. Recently, our earlier investigations revealed that using $0.6 \%$ of sodium metabisulfite (SMB; $\mathrm{Na}_{2} \mathrm{~S}_{2} \mathrm{O}_{5}$ ) was highly effective in maintaining the integrity and freshness of fruit and vegetable wastes by suppressing microbial proliferation and preserving the nutrient components $[5,6]$. Silage fermentation without SMB was not effective for preventing the deterioration and mold growth, which resulted in the rapid depletion of sugars and dry matter (DM) [6]. Therefore, the aim of this study was to evaluate nutritional value and rumen degradability of cabbage, Chinese cabbage and fruit-vegetable residues, and to examine feeding effects of these byproducts on performance of growing Hanwoo steers to determine its potential use as feedstuff for bovine feeding, which would contribute to minimizing its environmental impact.

\section{MATERIALS AND METHODS}

\section{Animal care}

The animal use and protocols employed during the research were reviewed and approved by the Institutional Animal Care and Use Committee at Konkuk University (Approval number: KU18129).

\section{Fruit-vegetable byproducts}

The fruit-vegetable byproduct was obtained from a wholesale fruit and vegetable distribution center (E-mart Fresh Center; Icheon, Gyeonggi, Korea), containing various types of fruits and vegetables (orange, apple, tomatoes, onion, bok choy, bell pepper, etc.). These byproducts tend to putrefy quickly because of their high content of moisture and simple carbohydrates. Thus, these byproducts were milled into 30 to $40 \mathrm{~mm}$ pieces, treated with $6 \mathrm{~g} / \mathrm{kg}$ of SMB, and stored in 110-L polyvinyl chloride bins to extend the length of storage. The level of SMB was determined by the results from Ahmadi et al [5].

Another byproduct consisting of cabbage and Chinese cabbage peels was produced from a traditional wholesale market in Seoul, Korea. These vegetables are particularly in large demand; thus, their byproducts occur constantly throughout the year. The vegetable byproducts were added in TMR diets as a raw material without pretreatment.

\section{Chemical analysis}

All samples of byproducts and TMR diets for chemical analysis were dried at forced-air oven connected to the sucking fan at $60^{\circ} \mathrm{C}$ for over 24 hours and ground through $2 \mathrm{~mm}$ screen using Wiley mill. Samples were analyzed for DM [7] (AOAC official method 930.15), crude protein (CP) [7] (AOAC official methods 930.15 and 990.03), fat [8] (AOAC official methods 930.15 and 2003.05), lignin [9], acid detergent fiber (ADF) [7] (AOAC official methods 930.15 and 973.18), neutral detergent fiber (NDF) [10], and ash [7] (AOAC official method 942.05).

\section{In situ dry matter degradability}

Two Holstein cows $(405 \pm 15.4 \mathrm{~kg})$ fitted with ruminal cannula were fed $4 \mathrm{~kg}$ of tall fescue and $3 \mathrm{~kg}$ of a formulated concentrate mix, divided into equal portions and offered daily at 09:00 and 18:00. The animals had free access to fresh water and mineral block. Rumen degradability of byproducts was determined using nylon bags $(10 \times 20 \mathrm{~cm}$ and $50 \mu \mathrm{m}$ of pore size; Ankom Technology, Macedon, NY, USA) and filled with approximately $4 \mathrm{~g}$ of sample. The ratio of sample size to bag surface area was equal to $10 \mathrm{mg} / \mathrm{cm}^{2}$, which is within the range (10 to $20 \mathrm{mg} / \mathrm{cm}^{2}$ ) recommended by the previous report [11] Triplicate bags were prepared in each animal for each incubation time.

Immediately after morning feeding, the bags containing the sample from fruit-vegetable, cabbage or Chinese cabbage byproduct were incubated in the ruminal ventral sac for 0,4 , $8,12,24,48,72,96$, and $120 \mathrm{~h}$. The time of entry into the rumen for each incubation time was adjusted to minimize the number of nylon bags staying in a rumen, instead of the 'all in/gradual out' [11] or the 'gradual addition/all out' schedule [12], thus maximum number of bags in the rumen at any one time was less than 15 . Thus, this method may be called 
gradual addition/gradual out. After incubation, bags were immediately washed in cold tap water until the rinsed water became clear, were dried at $65^{\circ} \mathrm{C}$ in a drying oven for $48 \mathrm{~h}$ and cooled in a desiccator and weighed. Bag residues of the same samples were then pooled for each time of incubation and analyzed for NDF with the analytical procedure [10].

The degradability of DM from nylon bag was fitted to the exponential model and effective degradability (ED) were calculated as follows [13]:

$$
\begin{aligned}
& \mathrm{P}=\mathrm{a}+\mathrm{b}\left(\mathrm{l}-\mathrm{e}^{-\mathrm{ct}}\right) \\
& \mathrm{ED}=\mathrm{a}+\mathrm{b} \times \mathrm{c} /(\mathrm{c}+\mathrm{k})
\end{aligned}
$$

Where, $\mathrm{P}$ is the $\mathrm{DM}$ degradability at time t, 'a' rapidly degradable fraction, ' $b$ ' the insoluble but potentially degradable fraction, 'c' constant for $b$ fraction, ' $\mathfrak{t}$ ' rumen suspension time and ' $\mathrm{k}$ ' outflow rates in rumen, assuming an outflow rate $(\mathrm{k})$ of 0.04 per hour.

\section{Animal trial}

Thirty-six growing steers (initial body weight [BW] $287 \pm 89$ $\mathrm{kg}, 9.1 \pm 2.7$ months) were randomly allocated into three experimental groups according to BW and age, consisting of three animals per pen in a total of 12 pens (4 replications/ treatment). After an adaptation period of 2 weeks, animals were fed the following experimental dietary treatments administered according to groups for 12 weeks. The treatments were control (byproduct $0 \%$ ), FV-B (fruit-vegetable byproduct $20 \%$, as fed basis), and CA-B (total byproduct $30 \%$ including cabbage peel $15 \%$ plus Chinese cabbage peel $15 \%$, as fed basis). TMR diets were formulated based on the Korean Feeding Standard for growing Hanwoo steers [14] to meet energy and protein requirements (total digestible nutrients [TDN] $73 \%$ and CP 16\%). Ingredients and chemical composition of the experimental diets are presented in Table 1 and 2, respectively. In addition, TMR diets fed were measured for in situ DM and NDF degradability. The method was carried out in the same manner as mentioned above.

Feeds were offered twice equally at 08:00 and 17:00 h daily. Animals could access fresh water and mineral block without any restriction during the whole period. Steers were weighed at the initial stage of the experiment and every 4 weeks (1st period, 0 to 4 weeks; 2 nd period, 5 to 8 weeks; 3 rd period, 9 to 12 weeks) before morning feeding. The DM intake (DMI) was measured every week for calculating feed conversion ratio (FCR) (feed/gain).

\section{Calculations and statistical analysis}

Non-fiber carbohydrate (NFC), TDN, and FCR value of experimental feeds were calculated as follows: i) NFC calculated by difference: $100-[\mathrm{CP}+(\mathrm{NDF}-\mathrm{NDICP})+\mathrm{EE}+\mathrm{ash}]$ [15]. ii)
Table 1. Formula of experimental TMR diets for growing Hanwoo steers (\%)

\begin{tabular}{lccc}
\hline Items $^{-}$ & (ontrol $^{1)}$ & FV-B $^{1)}$ & CA-B $^{1)}$ \\
\hline Corn flake & 18.6 & 18 & 20 \\
Fruit-vegetable byproduct & - & 20 & - \\
Chinese cabbage peel & - & - & 15 \\
Cabbage peel & - & - & 15 \\
Rice bran & 8 & 7 & 6 \\
Perilla meal & 7 & 7 & 6 \\
Lupine & 5 & 6 & 5.4 \\
Wheat bran & 5 & 2 & 4 \\
Alfalfa & 10 & 10 & 10 \\
Timothy & 17.8 & 17 & 17 \\
Water & 27 & 10.4 & - \\
Vitamin-mineral mix & 0.3 & 0.3 & 0.3 \\
Limestone & 1 & 1 & 1 \\
Salt & 0.3 & 0.3 & 0.3 \\
Total & 100 & 100 & 100 \\
\hline
\end{tabular}

TMR, total mixed rations (as fed basis).

${ }^{1)}$ Control, $0 \%$ of fruit or vegetable byproduct in TMR; FV-B, $20 \%$ of fruit-vegetable byproducts including various types of fruits and vegetables (orange, apple, tomatoes, onion, bok choy, bell pepper, etc.) in TMR; CA-B, 30\% of byproducts including Chinese cabbage peels (15\%) and cabbage peels (15\%) in TMR.

$\mathrm{TDN}=0.93 \times \mathrm{CP}+0.92 \times(1+\mathrm{EE}-\mathrm{ash}-\mathrm{CP}-\mathrm{NDF})+0.75 \times(\mathrm{NDF}-$ $\mathrm{ADL}) \times\left(1-\mathrm{ADL}^{2 / 3} /(\mathrm{NDF})^{2 / 3}\right)[16]$. iii) $\mathrm{FCR}=$ dry matter intake $(\mathrm{kg}) /$ gain $(\mathrm{kg})$. Where, NDICP, neutral detergent insoluble crude protein; EE, ether extract; ADL, acid detergent lignin.

Data obtained from in situ degradability and in vivo trial (BW, average daily gain [ADG], DMI, and FCR) were subjected to statistical analysis using the MIXED procedure of SAS (SAS Inst. Inc., Cary, NC, USA). For the in situ trial, the model included byproducts as the fixed effect and animals as the random effect. For the in vivo trial, the model included diets as the fixed effect and initial BW as the random effect. The pen was considered as the animal unit. The LSMEANS was used to calculate the mean values of treatments. Least

Table 2. Chemical composition of experimental TMR diets (DM basis, \%)

\begin{tabular}{lccc}
\hline Items & Control $^{\text {1) }}$ & FV-B $^{1)}$ & CA-B $^{1)}$ \\
\hline Dry matter & 63.81 & 64.39 & 66.20 \\
Crude protein & 16.37 & 17.22 & 16.32 \\
Ether extract & 5.83 & 6.17 & 5.30 \\
Ash & 8.08 & 8.00 & 8.49 \\
Neutral detergent fiber & 40.82 & 38.08 & 39.75 \\
Acid detergent fiber & 24.35 & 22.91 & 22.76 \\
Acid detergent lignin & 5.52 & 5.36 & 5.31 \\
Neutral detergent insoluble crude protein & 4.55 & 4.34 & 4.35 \\
Acid detergent insoluble crude protein & 1.25 & 1.05 & 1.13 \\
Total digestible nutrients & 72.08 & 73.41 & 71.77 \\
\hline
\end{tabular}

TMR, total mixed rations (as fed basis).

1) Control, $0 \%$ of fruit or vegetable byproduct in TMR; FV-B, 20\% of fruit-vegetable byproducts including various types of fruits and vegetables (orange, apple, tomatoes, onion, bok choy, bell pepper, etc.) in TMR; CA-B, $30 \%$ of byproducts including Chinese cabbage peels (15\%) and cabbage peels (15\%) in TMR. 
squares means among treatments were compared using the probability of difference (PDIFF) option when the treatment effect was significant. A p-value used for the determination of statistical significance was 0.05 .

\section{RESULTS AND DISCUSSION}

\section{Chemical analysis}

The chemical composition of byproducts is reported in Table 3. As expected, moisture concentrations of all byproducts were high, containing $90.40 \%, 93.75 \%$, and $85.19 \%$ for cabbage, Chinese cabbage, and fruit-vegetable byproducts, respectively. The high moisture content of leafy vegetables such as cabbage and Chinese cabbage has been known to negatively correlate with DMI $[17,18]$. Therefore, manufacturing TMR from these byproducts is necessary not only to reduce the moisture content but also to ensure economic feasibility in order to facilitate their inclusion in animal diets.

The DM of cabbage byproducts was relatively rich in protein. The CP concentrations of cabbage and Chinese cabbage were higher than that of fruit-vegetable. The variation in the $\mathrm{CP}$ content of each byproduct was also very low, having low standard deviation (SD). The CP content of cabbage was similar to the data (20.4\%) from Wadhwa et al [19] who reported the nutrient composition of cabbage peels. The $\mathrm{CP}$ values of fruit-vegetable found in this study were similar to those of Angulo et al [20] and Esteban et al [21], who found that fruit-vegetable byproduct contained $10 \%$ to $12 \%$.

Relatively higher NDF concentrations were observed in cabbage and Chinese cabbage than in fruit-vegetable, having $22.31 \%, 28.83 \%$, and $13.94 \%$, respectively. Fiber fractions of byproducts were more variable than other nutrient composition, having relatively higher SD values. For instance,
NDF content ranged from $14.25 \%$ to $27.07 \%$ for cabbage and $25.06 \%$ to $34.20 \%$ for Chinese cabbage byproducts. The present results were comparable to those from Ngu and Ledin [18], who reported that NDF of cabbage and Chinese cabbage were $27.9 \%$ and $25.3 \%$, respectively. Higher fiber fractions of cabbage peels were reported by Wadhwa et al [19], containing NDF 34.0\%, ADF 23.0\%, ADL 4.22\%. The variation in chemical composition can be attributed to the plant species, season, climate, and agronomic practices adapted in different regions [18]. Esteban et al [21] showed that crude fiber percentage of fruit-vegetable residue was $13 \%$ which was higher than the values found in this study. However, Angulo et al [20] reported even higher fiber fractions of fruit-vegetable (NDF 36.6\%, ADF 29.6\%) which varied by sampling period. Concentrations of ADL were relatively low, containing $1.90 \%$ for cabbage, $4.63 \%$ for Chinese cabbage and $4.62 \%$ for fruit-vegetable.

Higher amount of NFC was noted for fruit-vegetable (66.72\%) than cabbage (44.93\%) and Chinese cabbage byproducts $(24.69 \%)$. This was a part of the reason why SMB treatment was needed for fruit-vegetable, though the storage period was less than 5 days before manufacturing of TMR. The ash concentration of Chinese cabbage byproduct was very high $(29.15 \%)$, thereby lowering the concentration of NFC and TDN. Thus, major minerals and heavy metals were analyzed for all three byproducts to determine the presence of harmful minerals. However, the levels of heavy metals were negligible and far below the acceptance criteria of the Korea Ministry of Agriculture, Food and Rural Affairs (data not shown).

In situ DM and NDF degradability of byproducts: The in situ rumen DM degradability of byproducts is shown in Table 4 . At $0 \mathrm{~h}$ of incubation, the degradability of cabbage, Chinese

Table 3. Chemical composition of byproducts (DM basis, \%)

\begin{tabular}{|c|c|c|c|c|c|c|}
\hline \multirow{2}{*}{ Items } & \multicolumn{2}{|c|}{ Cabbage byproduct $^{1)}$} & \multicolumn{2}{|c|}{ Chinese cabbage byproduct $^{1)}$} & \multicolumn{2}{|c|}{ Fruit-vegetable byproduct ${ }^{1)}$} \\
\hline & Mean & SD & Mean & SD & Mean & SD \\
\hline Dry matter & 9.60 & 0.74 & 6.25 & 0.83 & 14.81 & 0.49 \\
\hline Crude protein & 18.69 & 0.53 & 20.20 & 0.60 & 10.07 & 0.33 \\
\hline Ether extract & 2.11 & 0.17 & 2.04 & 0.81 & 2.63 & 0.26 \\
\hline Crude fiber & 13.51 & 1.42 & 13.80 & 1.49 & 7.59 & 0.42 \\
\hline Ash & 13.67 & 0.87 & 29.15 & 3.85 & 6.65 & 0.36 \\
\hline Neutral detergent fiber & 22.31 & 4.67 & 28.83 & 3.61 & 13.94 & 3.24 \\
\hline Acid detergent fiber & 15.73 & 3.26 & 17.73 & 4.29 & 12.14 & 0.74 \\
\hline Acid detergent lignin & 1.90 & 0.91 & 4.63 & 1.47 & 4.62 & 0.40 \\
\hline Neutral detergent insoluble crude protein & 2.85 & 1.01 & 4.59 & 1.12 & - & - \\
\hline Acid detergent insoluble crude protein & 0.96 & 0.16 & 1.19 & 0.14 & - & - \\
\hline Non-fiber carbohydrate & 44.93 & 5.09 & 24.69 & 4.88 & 66.72 & 3.28 \\
\hline Total digestible nutrient & 73.30 & 2.62 & 53.53 & 5.56 & 79.53 & 0.89 \\
\hline
\end{tabular}

DM, dry matter; SD, standard deviation of samples.

1) Cabbage and Chinese cabbage byproducts mainly contain outer peels of the vegetable $(n=7)$ and fruit-vegetable byproduct contains byproduct from various types of fruits and vegetables $(n=7)$. 
Table 4. In situ rumen DM degradability and ED of byproducts (\%)

\begin{tabular}{|c|c|c|c|c|}
\hline Items & $\begin{array}{c}\text { Cabbage } \\
\text { byproduct }\end{array}$ & $\begin{array}{c}\text { Chinese } \\
\text { cabbage }^{1)} \text { byproduct }^{1)}\end{array}$ & $\begin{array}{c}\text { Fruit- } \\
\text { vegetable } \\
\text { byproduct }\end{array}$ & SEM \\
\hline \multicolumn{5}{|c|}{ Time (h) } \\
\hline 0 & $32.64^{\mathrm{a}}$ & $33.34^{\mathrm{a}}$ & $42.25^{\mathrm{b}}$ & 0.69 \\
\hline 4 & $51.48^{\mathrm{a}}$ & $49.97^{\mathrm{a}}$ & $68.35^{\mathrm{b}}$ & 1.97 \\
\hline 8 & $56.43^{b}$ & $51.15^{\mathrm{a}}$ & $74.03^{c}$ & 1.14 \\
\hline 12 & $58.10^{b}$ & $53.56^{\mathrm{a}}$ & $81.58^{c}$ & 1.35 \\
\hline 24 & $78.36^{\mathrm{a}}$ & $83.05^{\mathrm{a}}$ & $92.72^{b}$ & 1.68 \\
\hline 48 & $95.03^{b}$ & $90.29^{a}$ & $95.61^{b}$ & 0.42 \\
\hline 72 & $93.62^{b}$ & $90.99^{\mathrm{a}}$ & $95.79^{c}$ & 0.46 \\
\hline 96 & $92.54^{b}$ & $90.99^{\mathrm{a}}$ & $95.01^{c}$ & 0.40 \\
\hline 120 & $91.08^{\mathrm{a}}$ & $90.01^{\mathrm{a}}$ & $96.10^{b}$ & 0.65 \\
\hline \multicolumn{5}{|c|}{ Degradation characteristics of DM and ED²) } \\
\hline a & $34.47^{\mathrm{b}}$ & $26.32^{\mathrm{a}}$ & $50.20^{c}$ & 1.33 \\
\hline$b$ & $56.61^{b}$ & $63.90^{c}$ & $45.24^{\mathrm{a}}$ & 1.03 \\
\hline c & $0.060^{a}$ & $0.076^{b}$ & $0.129^{c}$ & $<0.01$ \\
\hline$a+b$ & $91.08^{a}$ & $90.22^{\mathrm{a}}$ & $95.44^{b}$ & 0.63 \\
\hline ED & $68.47^{\mathrm{a}}$ & $68.09^{a}$ & $84.69^{b}$ & 0.86 \\
\hline
\end{tabular}

DM, dry matter; ED, effective degradability; SEM, standard error of means.

1) Cabbage and Chinese cabbage byproducts, mainly contain outer peels of the vegetable; Fruit-vegetable byproduct, contains byproduct from various types of fruits and vegetables.

${ }^{2)}$ a, rapidly degradable fraction (\%); $b$, insoluble fraction but degraded over time in rumen $(\%) ; c$, constant for $b$ fraction in the exponential equation (fraction/h); $a+b$, potentially degradable fraction (\%); ED (\%), effective degradability calculated with outflow rates of $4 \%, t=120 \mathrm{~h}$.

${ }^{a-c}$ Means within a row without a common superscript letter differ at $p<0.05$.

cabbage and fruit-vegetable exceeded 30\%, and higher degradability was noticed $(\mathrm{p}<0.05)$ for fruit-vegetable $(42.25 \%)$ than for cabbage (32.64\%) and Chinese cabbage byproducts (33.34\%). After $4 \mathrm{~h}$ of incubation, the degradability for these byproducts reached more than $50 \%$. Similar to these results, Angulo et al [20] found that more than 50\% of fruit-vegetable was degraded at $2 \mathrm{~h}$, and more than $80 \%$ was degraded at 24 $\mathrm{h}$ for all periods. These results are mainly due to the highly soluble sugar and protein fractions of these byproducts. According to Wadhwa et al [19], leaves from cauliflower and cabbage have a high concentration of total sugars (18.6\% and $20.6 \%$, dry matter basis [DMB]) and water soluble protein fractions constituted the major portion (54\% to $62 \%$ ) of true protein of these vegetables.

The degradability of both cabbage and Chinese cabbage byproducts slightly increased from 4 to $12 \mathrm{~h}$, increased exponentially from 12 to $24 \mathrm{~h}$, then plateaued after $48 \mathrm{~h}$. Meanwhile, the degradation pattern of fruit-vegetable steadily increased until $24 \mathrm{~h}$ and then reached plateau. Although the difference was not large, the degradability was the highest in fruit-vegetable, followed by cabbage, and the lowest in Chinese cabbage byproducts during the whole incubation times $(\mathrm{p}<0.05)$. The ED of fruit-vegetable byproduct (84.69\%) were higher $(\mathrm{p}<$ 0.05 ) than those of cabbage (68.47\%) and Chinese cabbage byproducts (68.09\%). Similarly, the ED of residues containing half fruit and half vegetable was approximately $85 \%$ and not differed by the sampling periods [23]. Rumen DM degradability of tomato pulp, apple pulp and cauliflower were $47.1 \%, 89.1 \%$, and $93.8 \%$, respectively, suggesting that fruitvegetable was more degradable than tomato pulp and more like fruit degradation [24].

The in situ NDF degradability of byproducts is presented in Table 5. At the initial $0 \mathrm{~h}$ incubation time, the NDF degradability of cabbage, Chinese cabbage and fruit-vegetable was very high, being more than $46 \%$. Then, the pattern of NDF degradation of cabbage and Chinese byproducts was similar to that of DM, slowly increasing up to $12 \mathrm{~h}$, significantly increased between 12 and $24 \mathrm{~h}$, and reached plateau after $48 \mathrm{~h}$. On the other hand, the NDF fraction of fruit-vegetable was degraded exponentially from 12 to $48 \mathrm{~h}$, then reached plateau after $72 \mathrm{~h}$. Overall, the NDF degradability of fruitvegetable by-product except at $0 \mathrm{~h}$ was higher $(\mathrm{p}<0.05)$ than those of cabbage and Chinese cabbage by-products during the whole incubation time. The final NDF degradability of both cabbage and Chinese cabbage was approximately $66 \%$, whereas that of fruit-vegetable reached $92 \%$. This difference become more apparent when comparing digestion kinetics parameters. The rapidly degradable fraction 'a' of fruit-vege-

Table 5. In situ rumen NDF degradability and ED of byproducts (\%)

\begin{tabular}{ccccc}
\hline Items & $\begin{array}{c}\text { Cabbage } \\
\text { byproduct }\end{array}$ & $\begin{array}{c}\text { Chinese cabbage } \\
\text { byproduct }\end{array}$ & FV-B ${ }^{1)}$ & SEM \\
\hline Time (h) & & & & \\
0 & $49.94^{\mathrm{b}}$ & $46.10^{\mathrm{a}}$ & $47.87^{\mathrm{a}}$ & 0.46 \\
4 & $49.87^{\mathrm{a}}$ & $51.00^{\mathrm{a}}$ & $53.59^{\mathrm{b}}$ & 0.64 \\
8 & $50.37^{\mathrm{a}}$ & $53.35^{\mathrm{ab}}$ & $57.06^{\mathrm{b}}$ & 0.64 \\
12 & $52.22^{\mathrm{a}}$ & $56.52^{\mathrm{b}}$ & $58.46^{\mathrm{b}}$ & 0.56 \\
24 & $64.38^{\mathrm{a}}$ & $65.01^{\mathrm{a}}$ & $70.01^{\mathrm{b}}$ & 1.43 \\
48 & $67.85^{\mathrm{a}}$ & $66.05^{\mathrm{a}}$ & $86.34^{\mathrm{b}}$ & 0.71 \\
72 & $65.19^{\mathrm{a}}$ & $64.76^{\mathrm{a}}$ & $90.55^{\mathrm{b}}$ & 0.47 \\
96 & $66.08^{\mathrm{a}}$ & $66.74^{\mathrm{a}}$ & $89.23^{\mathrm{b}}$ & 0.65 \\
120 & $65.63^{\mathrm{a}}$ & $66.42^{\mathrm{a}}$ & $91.52^{\mathrm{b}}$ & 0.38 \\
Degradation characteristics of NDF and ED & & \\
a & $48.72^{\mathrm{a}}$ & $47.35^{\mathrm{a}}$ & $75.18^{\mathrm{b}}$ & 1.11 \\
$\mathrm{~b}$ & 16.91 & 19.07 & 16.34 & 1.02 \\
$\mathrm{c}$ & $0.030^{\mathrm{a}}$ & $0.025^{\mathrm{a}}$ & $0.072^{\mathrm{b}}$ & 0.01 \\
$\mathrm{a}+\mathrm{b}$ & $65.63^{\mathrm{a}}$ & $66.42^{\mathrm{a}}$ & $91.52^{\mathrm{b}}$ & 0.38 \\
ED & $55.97^{\mathrm{a}}$ & $54.22^{\mathrm{a}}$ & $85.62^{\mathrm{b}}$ & 0.78 \\
\hline
\end{tabular}

NDF, neutral detergent fiber; ED, effective degradability; SEM, standard error of means.

1) Cabbage and Chinese cabbage byproducts mainly contain outer peels of the vegetable $(n=7)$ and fruit-vegetable byproduct contains byproduct from various types of fruits and vegetables $(n=7)$.

${ }^{2)} \mathrm{a}$, rapidly degradable fraction (\%); b, insoluble fraction but degraded over time in rumen $(\%) ; c$, constant for $b$ fraction in the exponential equation (fraction/h); $a+b$, potentially degradable fraction (\%); ED (\%), effective degradability calculated with outflow rates of $4 \%, t=120 \mathrm{~h}$.

${ }^{a, b}$ Means within a row without a common superscript letter differ at $p<0.05$. 
table by-product $(75.18 \%)$ was much higher $(\mathrm{p}<0.05)$ than cabbage (48.72\%) and Chinese cabbage by-products (47.35\%). Consequently, The ED of NDF for fruit-vegetable byproduct $(85.62 \%)$ were higher $(\mathrm{p}<0.05)$ than those of cabbage $(55.97 \%)$ and Chinese cabbage byproducts (54.22\%). These results suggest that the NDF fraction of fruit-vegetable byproduct is more degradable than those of cabbage and Chinese cabbage byproducts.

\section{Animal performance}

The BW, DMI, ADG, and FCR of control and byproduct treatments are presented in Table 6 . Initial (0 day) BW of control, FV-B and CA-B were 288.8, 310.9, and $282.1 \mathrm{~kg}$, respectively. Final (12 weeks) BW were not different among treatments. In addition, there were no statistical differences among treatments during the middle of experimental days ( 4 and 8 weeks).

The average DMI during the whole period was not significantly different between treatments throughout the whole experimental period. This was because the ADG at the first period was already above the target gain $(<1.0 \mathrm{~kg})$ regardless of dietary treatments and the amount of TMR offered was kept constant according to the BW of steers to prevent overweight during the growing period. All animals were willing

Table 6. Effects of feeding byproducts on performance in growing Hanwoo steers

\begin{tabular}{lccccc}
\hline \multirow{2}{*}{ Items } & \multicolumn{3}{c}{ Treatments $^{1)}$} & \multirow{2}{*}{ SEM } & p-value \\
\cline { 2 - 4 } & Control & FV-B & CA-B & & \\
\hline BW (kg) & & & & & \\
0 wk & 288.8 & 310.9 & 282.1 & 23.044 & 0.068 \\
4th wk & 335.0 & 357.9 & 331.6 & 24.629 & 0.109 \\
8th wk & 370.7 & 392.0 & 359.6 & 23.749 & 0.154 \\
12th wk & 399.2 & 411.6 & 389.9 & 24.954 & 0.399 \\
DMl (kg/d) & & & & & \\
1st period) & 6.90 & 7.67 & 7.41 & 0.562 & 0.382 \\
2nd period & 7.16 & 7.61 & 7.23 & 0.674 & 0.481 \\
3rd period & 7.25 & 7.81 & 7.28 & 0.531 & 0.071 \\
Whole period & 7.06 & 7.63 & 7.15 & 0.585 & 0.180 \\
ADG (kg/d) & & & & & \\
1st period & 1.74 & 1.60 & 1.69 & 0.149 & 0.803 \\
2nd period & 1.15 & 1.28 & 1.04 & 0.076 & 0.152 \\
3rd period & 0.87 & 0.96 & 1.27 & 0.156 & 0.283 \\
Whole period & 1.26 & 1.25 & 1.34 & 0.122 & 0.859 \\
FCR (F/G) & & & & & \\
1st period & 4.17 & 5.02 & 4.47 & 0.560 & 0.553 \\
2nd period & 6.47 & 6.11 & 7.46 & 0.756 & 0.464 \\
3rd period & 8.50 & 7.97 & 7.48 & 1.288 & 0.859 \\
Whole period & 5.87 & 6.36 & 5.80 & 0.760 & 0.756 \\
\hline
\end{tabular}

SEM, standard error of means; BW, body weight; DMI, dry matter intake; $A D G$, average daily gain; $F C R$, feed conversion ratio.

1) Control, byproduct 0\%; FV-B, fruit-vegetable byproducts 20\%; CA-B, Chinese cabbage and cabbage byproducts $30 \%$.

2) 1st period ( 0 to $4 \mathrm{wk}$ ); 2 nd period ( 5 to $8 \mathrm{wk}$ ); 3 rd period ( 9 to $12 \mathrm{wk}$ ); whole period (0 to $12 \mathrm{wk}$ ). to consume more feeds than offered. Excessive daily gains during the growing period may lead to decreased or rejected feed intake at the end of the finishing period, resulting in reduced marbling deposits $[14,25]$. The ADG at the 1st, $2 \mathrm{nd}$, and 3rd period was not different among treatments, and thus the ADG during the entire experimental period was not different among treatments. According to NIAS [26], recommended levels of CP and TDN in feeds of Hanwoo steers at the growing period (up to 13-month-old) are 16\% and $72 \%$ to $73 \%$, respectively. The target ADG from 8- (BW 208 $\mathrm{kg}$ ) to 12 -month-old (BW $310 \mathrm{~kg}$ ) is 0.83 to $0.90 \mathrm{~kg}$. The TMR diet in this experiment was formulated to meet these nutrient requirements while maximizing the amount of by-products added. Consequently, the ADG of all treatments exceeded the value of the feeding standard with same levels of $\mathrm{CP}$ and TDN.

The in situ rumen DM and NDF degradability of the TMR diets fed to the experimental animals is presented in Table 7 and 8 , respectively. The DM degradability of control, FV-B and CA-B at $0 \mathrm{~h}$ was approximately $32 \%$, steadily increased to $80 \%$ until $48 \mathrm{~h}$, then slightly increased up to $86 \%$ thereafter. The digestion parameters such as a and $\mathrm{b}$ fractions, $\mathrm{ED}$ of $\mathrm{DM}$ degradability were not different among treatments. The NDF degradability of these diets showed little changes until $12 \mathrm{~h}$, but greatly increased from $66 \%$ to $84 \%$ for 12 to $48 \mathrm{~h}$. The ED of both DM and NDF degradability of the TMR diets were almost identical among treatments because TMR diets were

Table 7. In situ rumen DM degradability and ED of TMR diets (\%)

\begin{tabular}{lcccc}
\hline Items & Control $^{1)}$ & FV-B $^{1)}$ & CA-B $^{1)}$ & SEM \\
\hline Time (h) & & & & \\
0 & 31.03 & 32.77 & 31.69 & 0.61 \\
4 & 36.77 & 37.47 & 37.24 & 0.44 \\
8 & 40.59 & 41.31 & 39.78 & 0.71 \\
12 & 53.66 & 52.14 & 54.39 & 1.77 \\
24 & 69.85 & 70.46 & 68.67 & 1.90 \\
48 & 80.68 & 81.02 & 80.11 & 0.87 \\
72 & 82.54 & 82.34 & 82.70 & 0.84 \\
96 & 83.14 & 83.68 & 83.18 & 0.57 \\
120 & 85.82 & 86.06 & 85.19 & 0.30 \\
Degradation characteristics of DM and ED & & \\
a & 38.02 & 38.32 & 35.93 & 0.45 \\
b & 47.81 & 47.75 & 49.26 & 0.57 \\
c & 0.035 & 0.035 & 0.038 & 0.01 \\
a+b & 85.83 & 86.07 & 85.19 & 0.38 \\
ED & 60.26 & 60.69 & 59.90 & 0.78 \\
\hline
\end{tabular}

DM, dry matter; ED, effective degradability; TMR, total mixed ration; SEM, standard error of means.

1) Control, byproduct $0 \%$; FV-B, fruit-vegetable byproducts 20\%; CA-B, Chinese cabbage and cabbage byproducts $30 \%$.

2) a, rapidly degradable fraction (\%); b, insoluble fraction but degraded over time in rumen (\%); $c$, constant for $b$ fraction in the exponential equation (fraction/h); $a+b$, potentially degradable fraction (\%); ED (\%), effective degradability calculated with outflow rates of $4 \%, t=120 \mathrm{~h}$. 
Table 8. In situ rumen NDF degradability of TMR diets (\%)

\begin{tabular}{lcccc}
\hline Items & Control $^{1)}$ & FV-B $^{1)}$ & CA-B $^{1)}$ & SEM \\
\hline Time (h) & & & & \\
0 & 56.40 & 58.94 & 62.84 & 1.44 \\
4 & 60.43 & 62.37 & 63.98 & 1.72 \\
8 & 63.78 & 63.96 & 65.23 & 1.68 \\
12 & 65.17 & 65.45 & 68.25 & 0.98 \\
24 & 71.45 & 70.11 & 70.35 & 1.68 \\
48 & 84.05 & 82.71 & 83.40 & 0.96 \\
72 & 84.71 & 84.10 & 83.49 & 0.73 \\
96 & 85.60 & 83.84 & 86.29 & 0.42 \\
120 & 84.60 & 84.27 & 85.51 & 1.16 \\
Degradation characteristics of NDF and ED & & \\
a & 56.91 & 58.58 & 60.02 & 1.34 \\
b & 27.68 & 25.69 & 25.49 & 1.35 \\
C & 0.032 & 0.036 & 0.044 & 0.01 \\
a+b & 84.60 & 84.27 & 85.51 & 1.16 \\
ED & 69.00 & 70.78 & 72.81 & 1.11 \\
\hline
\end{tabular}

NDF, neutral detergent fiber; TMR, total mixed ration; SEM, standard error of means; ED, effective degradability.

1) Control (Byproduct 0\%); FV-B (Fruit-vegetable byproducts 20\%); CA-B (Chinese cabbage and cabbage byproducts 30\%); SEM, standard error of means.

${ }^{2)}$ a, rapidly degradable fraction (\%); b, insoluble fraction but degraded over time in rumen $(\%) ; c$, constant for $b$ fraction in the exponential equation (fraction/h); $a+b$, potentially degradable fraction (\%); ED (\%), effective degradability calculated with outflow rates of $4 \%, t=120 \mathrm{~h}$.

formulated at the same level of DM and NDF as well as other nutrients among treatments.

No statistical differences were noted for FCR among treatments during the whole experimental period. Froetschel et al [27] examined grocery byproduct feed (GBP) consisting of fruit, vegetables, and bakery items from large retail stores. Steers were fed $0 \%, 20 \%, 40 \%$, and $60 \%$ ensiled GBP in a TMR ( $90.8 \% \mathrm{DM}$ ), being equivalent to $0 \%, 18.2 \%, 36.3 \%$, and $54.4 \%$ of the ration DM. The highest intakes were observed at the $18.2 \%$ and $36.3 \%$ GBP inclusion rates. The nutrient composition of the ensiled GBP used was $17.7 \%$ DM, $12.3 \% \mathrm{CP}$, $14.1 \% \mathrm{NDF}, 6.6 \%$ ash, and $85 \%$ TDN. In this study, inclusion levels of byproducts were $20 \%$ for FV-B (13.2\% on DMB with $34 \%$ moisture) and $30 \%$ for CA-B (19.8\% on DMB with $34 \%$ moisture). The levels were close to the maximum level based on the feed formulation program [18] because relatively high concentrations of moisture and low TDN of these byproducts limit higher inclusion level in TMR diets in order to meet the requirement of growing Hanwoo cattle [11]. It was concluded that FV-B and CA-B can be used effectively as feed resources in TMR diets for cattle.

\section{CONCLUSION}

The use of FV-B up to $20 \%$ and CA-B up to $30 \%$ in TMR (as fed basis) did not show any negative effect on the performance of Hanwoo steers in the growing period. Therefore, these byproducts could serve as sources of nutrients for ruminants and can economize the production cost of animals.

\section{CONFLICT OF INTEREST}

We certify that there is no conflict of interest with any financial organization regarding the material discussed in the manuscript.

\section{ACKNOWLEDGMENTS}

This study was supported by 'Cooperative Research Program for Agriculture Science \& Technology Development (Project No. PJ012507012019)' Rural Development Administration, Republic of Korea.

\section{REFERENCES}

1. Porat R, Lichter A, Terry LA, Harker R, Buzby J. Postharvest losses of fruit and vegetables during retail and in consumers' homes: quantifications, causes, and means of prevention. Postharvest Biol Technol 2018;139:135-49. https://doi.org/ 10.1016/j.postharvbio.2017.11.019

2. FAO. Production - Crops. Cabbages and other brassicas [Internet]. FAO; c2019 [cited 2019 Aug] Available from: http:// www.fao.org/faostat/en/\#compare

3. Choi MH, Ji GE, Koh KH, Ryu YW, Jo DH, Park YH. Use of waste Chinese cabbage as a substrate for yeast biomass production. Bioresour Technol 2002;83:251-3. https://doi.org/ 10.1016/S0960-8524(01)00232-2

4. Kim YS, Phae CG. Analysis of generation characteristics for fruit and vegetables byproducts generated in $\mathrm{G}$ public agricultural wholesale market. J Korea Soc Waste Manag 2019;36: 49-54. https://doi.org/10.9786/kswm.2019.36.1.49

5. Ahmadi F, Lee YH, Lee WH, Oh YK, Park KK, Kwak WS. Preservation of fruit and vegetable discards with sodium metabisulfite. J Environ Manage 2018;224:113-21. https://doi. org/10.1016/j.jenvman.2018.07.044

6. Ahmadi F, Lee YH, Lee WH, Oh YK, Park KK, Kwak WS. Long-term anaerobic conservation of fruit and vegetable discards without or with moisture adjustment after aerobic preservation with sodium metabisulfite. Waste Manage 2019; 87:258-67. https://doi.org/10.1016/j.wasman.2019.02.010

7. AOAC. Official methods of analysis. 17th ed. Arlington, VA, USA: AOAC Int.; 2000.

8. AOAC. Official methods of analysis. 18th ed. Arlington, VA, USA: AOAC Int.; 2006.

9. Goering HK, Van Soest PJ. Forage fiber analysis. USDA, superintendent of documents. Washington, DC, USA: USDA Agricultural Research Service; 1970. Handbook number 379.

10. Van Soest PJ, Robertson JB, Lewis BA. Methods for dietary fiber, neutral detergent fiber, and nonstarch polysaccharides 
in relation to animal nutrition. J Dairy Sci 1991;74:3583-97. https://doi.org/10.3168/jds.S0022-0302(91)78551-2

11.Nocek JE. In situ and other methods to estimate ruminal protein and energy digestibility: a review. J Dairy Sci 1988;71: 2051-69. https://doi.org/10.3168/jds.S0022-0302(88)79781-7

12. Michalet-Doreau B, Ould-Bah MY. In vitro and in sacco methods for the estimation of dietary nitrogen degradability in the rumen: a review. Anim Feed Sci Technol 1992;40:57-86. https://doi.org/10.1016/0377-8401(92)90112-J

13. Ørskov ER, McDonald I. The estimation of protein degrability in the rumen from incubation measurements weighted according to rate of passage. J Agric Sci 1979;92:499-503. https://doi. org/10.1017/S0021859600063048

14. National Institute of Animal Science. Korean feeding standard for Hanwoo. 4th Ed. Jeonju, Korea: Rural Development Administration; 2017.

15. Van Soest PJ, Robertson JB, Lewis BA. Methods for dietary fiber, neutral detergent fiber, and nonstarch polysaccharides in relation to animal nutrition. J Dairy Sci 1991;74:3583-97. https://doi.org/10.3168/jds.S0022-0302(91)78551-2

16. Conrad HR, Weiss WP, Odwongo WO, Shockey WL. Estimating net energy lactation from components of cell solubles and cell walls. J Dairy Sci 1984;67:427-36. https://doi.org/10. 3168/jds.S0022-0302(84)81320-X

17. Gupta R, Chauhan TR, Lall D. Nutritional potential of vegetable waste products for ruminants. Bioresour Technol 1993;44: 263-5. https://doi.org/10.1016/0960-8524(93)90162-5

18. Ngu NT, Ledin I. Effects of feeding wastes from Brassica species on growth of goats and pesticide/insecticide residues in goat meat. Asian-Australas J Anim Sci 2005;18:197-202. https:// doi.org/10.5713/ajas.2005.197

19. Wadhwa M, Kaushal S, Bakshi MPS. Nutritive evaluation of vegetable wastes as complete feed for goat bucks. Small Rumin Res 2006;64:279-84. https://doi.org/10.1016/j.smallrumres. 2005.05.017

20. Angulo J, Mahecha L, Yepes SA, et al. Quantitative and nutri- tional characterization of fruit and vegetable waste from marketplace: A potential use as bovine feedstuff? J Environ Manage 2012;95:S203-9. https://doi.org/10.1016/j.jenvman. 2010.09.022

21.Esteban MB, Garcia AJ, Ramos P, Marquez MC. Evaluation of fruit-vegetable and fish wastes as alternative feedstuffs in pig diets. Waste Manage 2007;27:193-200. https://doi.org/10. 1016/j.wasman.2006.01.004

22. Garcia AJ, Esteban MB, Marquez MC, Ramos P. Biodegradable municipal solid waste: characterization and potential use as animal feedstuffs. Waste Manage 2005;25:780-7. https://doi. org/10.1016/j.wasman.2005.01.006

23. Karkoodi K, Fazaeli H, Mirghaffari S. Assessing the nutritive value of fruit and vegetable residues as ruminant feed. Turk J Vet Anim Sci 2012;36:239-44. https://doi.org/10.3906/vet1008-22

24. Gasa J, Castrillo C, Baucells MD, Guada JA. By-products from the canning industry as feedstuff for ruminants: digestibility and its prediction from chemical composition and laboratory bioassays. Anim Feed Sci Technol 1989;25:67-77. https://doi. org/10.1016/0377-8401(89)90108-9

25. Chung KY, Lee SH, Cho SH, Kwon EG, Lee JH. Current situation and future prospects for beef production in South Korea — a review. Asian-Australas J Anim Sci 2018;31:951-60. https:// doi.org/10.5713/ajas.18.0187

26. National Institute of Animal Science. Korean feeding standard program for Hanwoo [Internet]. National Institute of Animal Science; c2015 [2019 May]. Available from: http://www.nias. go.kr/front/researchUtilizeBoardView.do? $\mathrm{cmCode}=\mathrm{M} 0909$ $18001117679 \&$ cntntsNo=8507\&columnName=title\&searc hStr $=$

27. Froetschel MA, Ross CL, Stewart Jr. RL, Azain MJ, Michot P, Rekaya R. Nutritional value of ensiled grocery food waste for cattle. J Anim Sci 2014;92:5124-33. https://doi.org/10. 2527/jas.2014-8126 